
\title{
THE EFFECTS OF IMPLEMENTING 5S
AS THE FOUNDATION FOR WORK IMPROVEMENT
ON THE WORKPLACE \\ sciendo
}

doi:10.2478/mape-2018-0057

Date of submission of the article to the Editor: $03 / 2018$

Date of acceptance of the article by the Editor: $07 / 2018$

MAPE 2018, volume 1, issue 1, pp. 451-455

Mgr inż. Celina Bartnicka

University of Warmia and Mazury in Olsztyn, Poland

\begin{abstract}
The article presents the main aspects which require attention when optimizing and improving the manufacturing process, i.e.: the human resources aspect, the technical aspect and the organizational aspect. Concepts such as the Total Quality Management, Six Sigma or Lean Manufacturing claim that work improvement should be a continuous process. The foundation for implementing the improvement of processes, regardless of the concept, are well-organized and orderly workplaces as well as standardization, which can be achieved thanks to the Japanese $5 \mathrm{~S}$ method.
\end{abstract}

Keywords: 5 S method, work optimization, improvement of processes

\section{INTRODUCTION}

Today fast market changes require proper tools that enable successful implementation of savings and aimed at cost reduction is a serious challenge. However it is an absolute must to retain ones position on the global market in a constantly changing environment. In order to achieve highest results companies must constantly involve themselves in optimization both the process and the work station that are located within them. Therefore companies are looking for proven methods that will ensure them efficiency, but also will not require large financial commitment. The basis for implementing optimization is good organization of work at the position. In order to organize the position, to ensure the adapt of the standard and to have useful tools, the Japanese $5 \mathrm{~S}$ method is used.

\section{THE MAIN ASPECTS OCCURRING DURING WORK OPTIMISATION}

During optimization and improvement of the manufacturing process, regardless of the type of work done at the workplace, attention should be paid to the three most important aspects:

- the human resources aspect;

- the technical aspect;

- the organizational aspect.

The priority of the analysis regarding these aspects is to eliminate anything that does not add value to the product, in order to optimize the costs, minimize the use of resources as well as to reduce the machine downtime and the stock.

In the aspect of human resources attention should be paid to efficiency, flexibility and constant development of competences. The company success is achieved by permanent training in technical areas, specialist knowledge, but also in soft skills acquisition, such as: efficient communication, ability to work in a team, creativity, or effective time management. In order to increase flexibility, it is essential to multitask, which also eliminates the monotonous nature of work. In addition, the employees should identify with the company values, treat their colleagues with respect and continuously work on improving their interpersonal relations. People constitute the foundation of effective operation of the company, and therefore without their motivation to work, it does not have a chance of survival. 
The technical aspect suggests the development of workplace optimization, elimination of operations which are unnecessary from the client's perspective. An example of elements with no added value are logistic operations, which should be minimized. It is essential here to rely on standardization. A further step is to eliminate operations which are physically and mentally arduous, through implementation ergonomic solutions. Along with the advancement of technology, automation of processes is at least partly implemented. To ensure the effective use of machines it is necessary to focus on eliminating downtime, failures and causes of quality defects. It is important to manage the process by means of visualizations. Light boards, indicators and signal lamps, etc. are used for this purpose.

The organizational aspect takes into account synchronized production, focusing on results, elimination of bottlenecks, development of client/supplier relationships, reduction of lead time. As part of process optimization flexible production lines are built to ensure easy management of product changes, reduction of stock and fast shipment of goods to the client. Layout should be analyzed, which may be chaotic and unsuited to work at a particular workplace. Ensuring efficient organization of workplaces starts with the introduction of 5S. Essential things to analyze are the input elements for production and their availability, costs, quality and quantity of generated waste, which is usually one of the most important optimization points.

Actions in these three aspects are often comprehensive - regardless of the manufacturing process characteristics, they should aim at bringing the system to excellence (Łuczak, 2007).

\section{CONCEPTS OF PROCES IMPROVEMENT}

It is possible to improve work continuously, which is based on constant development through gradual problem solving and streamlining activities performed as part of such concepts as: Total Quality Management, Six Sigma or Lean Manufacturing. These concepts are convergent to a certain extent, i.e. they put client satisfaction first, and they strive to ensure it by eliminating waste and increasing efficiency of production processes. In addition, in each of the aforementioned concepts elements important for optimization can be identified:

- the system - it organizes tasks in the company, determines the scope of responsibility and authority;

- the teams - it is necessary to engage all employees (and not just the management), who will find it important to raise the quality and meet the clients' requirements, properly organized teams should strive to continuously improve the quality and methods of manufactured products and streamline executed processes;

- the tools and methods - using appropriate tools and methods to optimize, improve and monitor processes.

As a result of convergent assumptions, the use of Total Quality Management, Six Sigma or Lean Manufacturing generates the use of very similar or identical tools and methods which are key for optimization. Every concept is based on the principle of a well-organized and orderly workplace and standardization, which can be achieved thanks to the Japanese $5 S$ method (Mikuła, 2006).

\section{THE 5S METHOD}

Building of the production system, especially in the Lean Manufacturing philosophy, is presented as the Quality Function Deployment (QFD). In QFD (quality house) the $5 S$ method is included in the system's foundation, as the newly established standard, order and stability make it possible to perform the analysis in terms of improvement (Basistova et al., 2016). The Figure 1 presents an example of a quality house. 


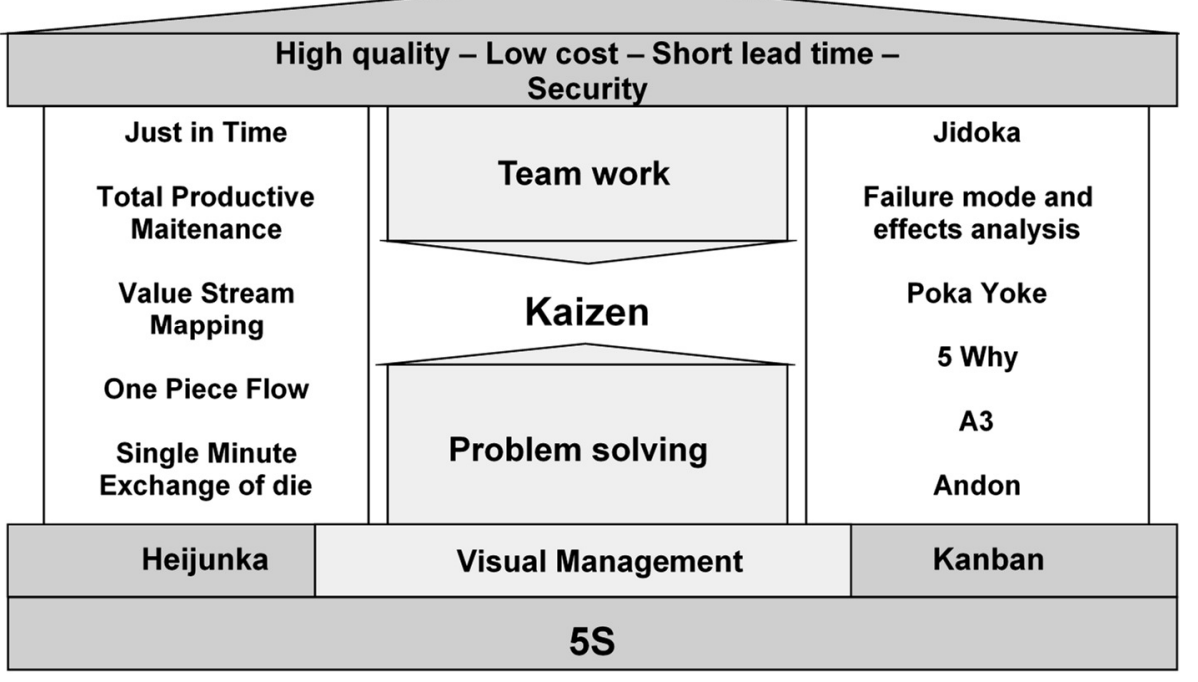

Fig. 1. Quality house in the Lean Manufacturing philosophy

The $5 \mathrm{~S}$ method derives from the automotive industry, from the Toyota factory. It is based on many years of observations of organizations and working methods of Japanese workers (Gapp et al., 2008).

The 5S method is introduced as the starting point for optimization activities. Due to the implementation of the $5 \mathrm{~S}$ method the workplace area changes but also the operators become more engaged (Gajewski, 2007). The main idea of the 5 s method is presented in the Figure 2.

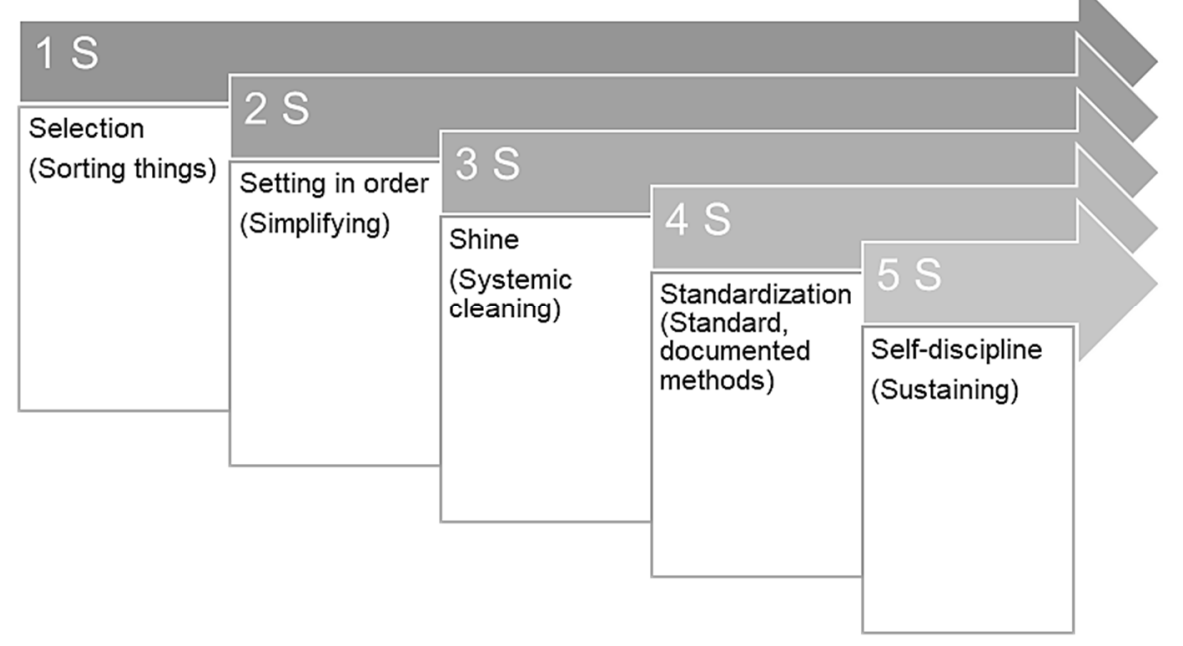

Fig. 2. The main idea of the $5 \mathrm{~s}$ method

The main aim of the first $\mathrm{S}$ - selection (seiri in Japanese) is the elimination of losses resulting from unnecessary movement of tools and materials as well as losses resulting from searching for them (Grudziewski, 2004).

Further elements of the $5 \mathrm{~S}$ - setting in order (seiton), shine (seiso), standardization (seiketsu) and self-discipline (shitsuke) - help to develop good working habits, which are very important in further stages of implementing optimization (Karaszewski, 2006).

The first step of selection says that only things necessary and essential for performing tasks should be present at the workplace. As part of this stage, a red-cards action can be carried out, where only necessary tools and instruments should be identified and all the others should be marked with a red card and put aside in the red zone. Elements selected in this way are removed from the workplace. Less frequently used tools are moved to a closet or predefined 
storeroom. Remaining tools and instruments are placed in drawers, on shelves and in containers - with the most frequently used tools being stored at a higher level (KuczyńskaChałada, 2017).

As a result of setting things in order, every item has its own place, the rules of tools storage and use are defined. It is important to maximally adapt the workplace to the tasks that need to be performed on it. Tools, cabinets and shelves should be marked. Diagrams of equipment corresponding to the markings can be introduced or create a board of shadows which will make it easier for the employee to put the tools back in their place and be informed of their absence. Minimum and maximum levels of spare elements and liquids are defined. Zoning is created, which means that areas dedicated to specific things are outlined on the floor (Predon and Raszka, 2009).

The principle of shine ensures that the workplace is neat and clean. It is a good idea to create a clean-up corner so as not to waste time looking for and bringing cleaning equipment form a remote part of the hall. Keeping the state of cleanliness will ensure that the workplace is ready to use (Pawlak, 2004).

Good functioning of the workplace is guaranteed by standardization. The standard needs to be defined and apply to everyone, it should become a habit. Standard involves work instructions, procedures, check-lists (Gajdzik and Wycislik, 2016).

Teams should be held accountable for maintaining cleanliness and observing the applicable standards through audits. The system also needs to undergo sustainable improvement and self-discipline. It can be ensured through daily monitoring of key performance indicators and analyzing deviations from the defined goal (Liker and Meier, 2011).

The $5 \mathrm{~S}$ method increases efficiency of the production process, which translates into the quality of manufactured elements. Properly stored tools and instruments maintain their usability for longer. By eliminating redundant items the working area gives the user freedom of movement. Everything has its own place, searching for tools and waste are avoided. Schedules and checklists indicate all irregularities. Implementing the $5 \mathrm{~S}$ method results in an orderly process and safety of work (Imai, 2006).

\section{CONCLUSION}

The 5S system shapes the organizational culture of the company, and above all it is a foundation for implementing and maintaining tools that improve processes, such as Total Productive Maintenance, Value Stream Mapping, One Piece Flow, Single Minute Exchange of die etc. $5 \mathrm{~S}$ is an element of the visual control process. The developed standards through $5 \mathrm{~S}$ allow for easy identification of problems. As a result, it is possible to start the analysis of processes currently carried out and improve those things which can work better (Jaca et al., 2014).

The 5S method can be applied to all aspects of a company, e.g. production, logistics, warehouses, maintenance, administration. The assumptions, regardless of the chosen area, remain the same, hence the universal nature of this method (Jędrzejak et al., 2014).

The $5 \mathrm{~S}$ eliminates losses, systematizes tasks and tools and organizes the workplace. As a result of the implemented standardization and self-discipline, the effects are long-lasting and become employees' habits. The results of introducing the $5 \mathrm{~S}$ method make the foundation for implementing further optimizing actions and improvement of processes in the aspect of human resources as well as the technical and organizational aspects.

\section{REFERENCES}

Basistova, A., Stankovic, L., Ferencova, M., Haluska, R. (2016). Creating productive and arranged workplace through 5S method in a company. Production Management And Engineering Sciences, Apr 16-17, pp. 7-13.

Gajdzik, B., Wycislik, A. (2016). Framework for the implementation of the 5 S method in the chemical laboratory. Przemysl Chemiczny, 95(2), pp. 176-179. 
Gajewski, A. (2007). Wstęp do zarządzania jakością. Wydawnictwo Małopolskiej Wyższej Szkoły Ekonomicznej w Tarnowie, Tarnów, pp. 172-173.

Gapp, R., Fisher, R., Kobayashi, K. (2008). Implementing 5S within a Japanese Context: An Integrated Management System. Management Decision, 46(4), pp. 565-579.

Grudziewski, W.M. (2004). Metody projektowania systemów zarządzania. Warszawa: Difin, pp. 14.

Imai, M. (2006). Gemba Kaizen. Zdroworozsądkowe, niskokosztowe podejście do zarządzania. Warszawa: MT Biznes, , pp. 104.

Jaca, C., Viles, E., Paipa-Galeano, L., Santos, J., Mateo, R. (2014). Learning 5 S principles from Japanese best practitioners: case studies of five manufacturing companies. International Journal Of Production Research, 52(15), pp. 4574-4586.

Jędrzejak, A., Mazur, A., Piotrowska, M. (2014). Praktyczne aspekty wdrażania metody 5-S. Poznań: Zeszyty Naukowe Politechniki Poznańskiej, 62, pp. 61-68.

Karaszewski, R. (2006). Nowoczesne koncepcje zarzadzania jakością. Toruń: Towarzystwo Naukowe Organizacji i Kierownictwa, pp. 226-227.

Kuczyńska-Chałada, M. (2017). Proces wdrożenia metody 5S w przedsiębiorstwie produkcyjnym. Innowacje w Zarządzaniu i Inżynierii Produkcji, Opole: Oficyna Wydawnicza Polskiego Towarzystwa Zarządzania Produkcją, tom I, pp. 604-610.

Liker, J.K., Meier, D.P. (2011). Droga Toyoty. Fieldbook. Praktyczny przewodnik wdrażania 4P Toyoty. Warszawa: Wydawnictwo MT Biznes, pp. 97.

Łuczak, J. (2007). Metody i techniki zarządzania jakością: kompendium wiedzy. Poznań: Quality Progress, pp. 339-340.

Mikuła, B. (2006). Organizacje oparte na wiedzy. Kraków: Wydawnictwo Akademii Ekonomicznej w Krakowie, pp. 180-181.

Pawlak, W. (2004). O praktykach 5S ponownie. Problemy jakości, 4, pp. 40.

Predoń, B., Raszka, A. (2009). Dlaczego program 5S czasami nie działa?. Problemy Jakości, 5, pp. 12 